DZIEJE NAJNOWSZE, ROCZNIK XLVII - 2015, 3

PL ISSN 0419-8824

\author{
A U T O R E F E R A T Y
}

Justyna Dudek

Lublin

\title{
Marian Gołębiewski (1911-1996). Biografia żołnierza, opozycjonisty i emigranta*
}

Osoba Mariana Gołębiewskiego, której poświęcona jest moja rozprawa, to postać niezwykle ciekawa, choć raczej mało znana szerszemu gronu historyków. Żołnierz Polskich Sił Zbrojnych na Zachodzie; cichociemny; dowódca Kedywu Armii Krajowej na Zamojszczyźnie; komendant Obwodu Hrubieszów AK; inspektor Inspektoratu Zamość Delegatury Sił Zbrojnych; zastępca i szef sztabu Komendy Okręgu Lubelskiego Zrzeszenia Wolność i Niezawisłość; sądzony w procesie pokazowym I Zarządu Głównego WiN; długoletni więzień polityczny, a po 1956 r. aktywny opozycjonista; jeden z założycieli organizacji „Ruch”, później związany z Ruchem Obrony Praw Człowieka i Obywatela, natomiast w latach osiemdziesiątych działacz emigracyjny — to najważniejsze z funkcji, które przyszło mu pełnić w życiu.

Barwny i bogaty życiorys Mariana Gołębiewskiego mógłby posłużyć za kanwę niejednej sensacyjnej książki czy filmu. W jego biografii roi się od brawurowych ucieczek i nagłych zwrotów akcji, z których niczym filmowy bohater wychodzi obronną ręką. Nie jest to jednak główny powód przemawiający za podjęciem tej tematyki. Perspektywa jego indywidualnych losów pozwala prześledzić skomplikowaną i trudną historię Polski i Polaków w XX w. Waga wydarzeń, w których uczestniczył, była znaczna, a on sam spotkał na swojej drodze wiele czołowych postaci z kart polskiej historii. Przez całe życie w różnej formie angażował się w działalność polityczną i niewątpliwie można go zaliczyć do grona najaktywniejszych działaczy niepodległościowych, pomimo spotykanych represji ze strony władzy komunistycznej. Pod względem ,stażu” należał do najdłużej przetrzymywanych więźniów politycznych PRL. Łącznie w komunistycznych więzieniach spędził 14 lat, 7 miesięcy i 6 dni. Swoją nie-

\footnotetext{
* Autoreferat pracy doktorskiej obronionej 10 III 2015 r. na Wydziale Nauk Humanistycznych Katolickiego Uniwersytetu Lubelskiego Jana Pawła II, napisanej pod kierunkiem dr. hab. Rafała Wnuka (prof. KUL). Recenzentami pracy byli: dr hab. Marek Wierzbicki (prof. KUL) oraz dr hab. Grzegorz Motyka (prof. ISP PAN).
} 
ugiętą postawą wyróżniał się w środowisku żołnierzy Armii Krajowej i powojennej konspiracji. Za podjęciem tej tematyki przemawiał również fakt, że dotychczas nikt nie podjął się opracowania jego pełnej biografii. W literaturze przedmiotu pojawiały się artykuły biograficzne, pisano o nim w kontekście wydarzeń, których był uczestnikiem, jednak żadna z tych prób nie wyczerpała tematu.

Celem przedstawionej rozprawy było zaprezentowanie w możliwie szerokiej perspektywie biografii Mariana Gołębiewskiego. Jest to zatem biografia w klasycznym rozumieniu tego gatunku.

Pytania badawcze, które sobie stawiałam, odnosiły się do jego indywidualnych losów. Przygotowując pracę, chciałam poznać elementy, które go ukształtowały i sprawiły, że wybrał właśnie taką drogę życiową. Zamierzałam pokazać rolę, jaką odegrał w strukturach wojennej i powojennej konspiracji, gdyż ze względu na pełnione funkcje miał wpływ na kształtowanie się wydarzeń na Lubelszczyźnie w okresie 1943-1946. Jego osoba ściśle łączy się z zagadnieniem stosunków polsko-ukraińskich w tym regionie. Jako szef Kierownictwa Dywersji w Inspektoracie Zamość AK, a następnie komendant Obwodu Hrubieszów AK opowiadał się za siłowym rozwiązaniem kwestii ukraińskiej, forsując w marcu 1944 r. idee odwetowego ataku na ukraińskie wioski uznane za bazy ukraińskiej partyzantki. Zastanawiałam się następnie, z czego wynikał fakt, że po zakończeniu niemieckiej okupacji i wkroczeniu w lipcu 1944 r. na Lubelszczyznę Armii Czerwonej właśnie Gołębiewski stał się głównym propagatorem zaprzestania wyniszczającej walki z UPA. Efektem tego było spotkanie $21 \mathrm{~V} 1945 \mathrm{r}$. w przysiółku Żar niedaleko Rudy Różanieckiej przedstawicieli Inspektoratu Zamość DSZ z jednej strony a OUN-UPA z drugiej, w trakcie którego doszło do zawarcia nieformalnego porozumienia, które przyczyniło się do przerwania wzajemnej fali przemocy. Dalej, jakie strategie przetrwania przyjął on w czasie prowadzonych przeciwko niemu śledztw i uwięzienia? Czy pomimo postawy antysystemowej możemy mówić w jego przypadku o jakichkolwiek mechanizmach przystosowawczych? Zamierzałam ponadto jak najpełniej przedstawić jego aktywność emigracyjną po 1982 r. i zmianach demokratycznych w Polsce, która pozostaje najbardziej kontrowersyjna, próbując jednocześnie odpowiedzieć na pytanie, dlaczego nie udało mu się odegrać znaczącej roli na emigracji i z czego wynikał fakt negowania polskiej niepodległości po $1989 \mathrm{r}$.

Opracowując ten temat, przeanalizowałam dostępną literaturę naukową, popularnonaukową, pamiętnikarską, a także prasę. Jednak kluczowe znaczenie miała przede wszystkim kwerenda dokumentów archiwalnych. Rozprawa została oparta na materiale źródłowym pochodzącym zarówno z archiwów krajowych, jak i zagranicznych, zbiorów prywatnych, kolekcji zgromadzonych w bibliotekach i muzeach, relacjach, a także materiale fotograficznym. Łącznie odwiedziłam przeszło trzydzieści miejsc, gdzie odnalazłam materiały niezbędne do napisania dysertacji. Choć wykorzystana baza źródłowa jest szeroka, szczególnie odczuwalny był jej brak dla lat przedwojennych.

Wspomnę szerzej jedynie o kilku z nich ze względu na wagę materiałów tam zgromadzonych. Duża grupa źródeł wykorzystanych przeze mnie znajdowała się w zasobach Instytutu Pamięci Narodowej w Warszawie oraz jego oddziałach w Gdańsku, Lublinie, Łodzi, Kielcach, Krakowie, Poznaniu, Radomiu oraz Wrocławiu. Zostały one wytworzone w okresie kilkudziesięciu lat przez różne komórki UB i SB. Materiały te stanowiły istotny korpus źródeł z tego względu, że opisywana przeze mnie postać aż trzykrotnie stawała przed komunistycznym wymiarem sprawiedliwości — w różnych okresach i odmiennych uwarunkowaniach politycznych. Mam tu na myśli proces I Zarządu Głównego Zrzeszenia Wolność i Niezawisłość ze stycznia 1947 r., śledztwo i proces dotyczący nieudanej ucieczki z więzienia w Sieradzu z lutego 1956 r. oraz postępowanie przeciwko przywódcom tajnej organizacji „Ruch” z jesieni 1971 r. Poza tym korzystałam w pracy z dokumentów administracyjnych, 
operacyjnych, wewnętrznych opracowań resortowych czy materiałów organizacyjnych (AK, WiN) przejętych przez tajną policję polityczną.

Kolejna grupa dokumentów to prywatne zbiory Mariana Gołębiewskiego, znajdujące się obecnie w posiadaniu jego syna oraz w Instytucie Józefa Piłsudskiego w Nowym Jorku, które miały kluczowe znaczenie dla ukazania jego działalności na emigracji i stosunku wobec przemian zachodzących w kraju po 1989 r. Wartościowe okazały się także dwa zbiory dokumentów z Archiwum Emigracji w Toruniu - materiały samozwańczego „prezydenta” na uchodźstwie Juliusza Nowiny-Sokolnickiego i założyciela organizacji „Wolna Polska” Konstantego Zygfryda Hanffa, z którymi Gołębiewski przez jakiś czas współpracował w latach osiemdziesiątych w Stanach Zjednoczonych.

Spośród archiwów zagranicznych, oprócz wspomnianego Instytutu Józefa Piłsudskiego w Nowym Jorku, korzystałam ze zbiorów Studium Polski Podziemnej w Londynie, w szczególności z kolekcji akt personalnych żołnierzy cichociemnych, materiałów Oddziału VI Sztabu Naczelnego Wodza oraz relacji, w tym również wspomnień. Płk. Jana Rzepeckiego. Z kolei w Instytucie Polskim i Muzeum im. gen. Sikorskiego w Londynie przeglądałam następujące zespoły dokumentów: rozkazy dzienne 1 Brygady Strzelców i 4 Kadrowej Brygady Strzelców, kolekcję Józefa Hartmana, a także wspomnienia Michała Protasewicza, szefa Oddziału VI Sztabu Naczelnego Wodza.

Niektóre dokumenty znajdujące się w zagranicznych archiwach i instytucjach uzyskałam drogą korespondencyjną: z Urzędu Emigracyjnego w Stanach Zjednoczonych (Citizenship and Immigration Service) czy z Archiwum Ministerstwa Obrony Wielkiej Brytanii (Ministry of Defence); tak było również w przypadku materiałów z Instytutu Józefa Piłsudskiego w Nowym Jorku.

Przebadałam także zasoby Archiwum Akt Nowych w Warszawie, gdzie korzystałam z zespołów Departamentu Więziennictwa, Sądu Najwyższego-Izby Karnej czy spuścizny Władysława Siły-Nowickiego. Z kolei w Archiwum Państwowym w Lublinie zapoznałam się ze zbiorami Armii Krajowej, Zrzeszenia Wolność i Niezawisłość oraz Związku Bojowników o Wolność i Demokrację.

Mniejszej wagi materiały, choć mające znaczenie dla ukazania działalności tej postaci, przyniosły kwerendy w Bibliotece Uniwersytetu Warszawskiego (zbiory Biura Informacji i Propagandy KG AK), Muzeum w Hrubieszowie (dokumenty Obwodu Hrubieszów AK), Centralnym Archiwum Wojskowym, Zakładzie Narodowym im. Ossolińskich we Wrocławiu, Wojewódzkiej Bibliotece Publicznej w Lublinie (zbiory Ireneusza Cabana i Zygmunta Mańkowskiego), Instytucie Literackim w Paryżu (korespondencja Mariana Gołębiewskiego i Wacława Soroki z Jerzym Giedroyciem), Zakładzie Historii Ruchu Ludowego w Warszawie (Korespondencja Franciszka Wilka) oraz Archiwum w Mławie, gdzie zgromadzone akta metrykalne z XIX i XX wieku pozwoliły na pokazanie korzeni rodzinnych Gołębiewskiego.

Uzupełnieniem źródeł archiwalnych i opublikowanych były zebrane przeze mnie relacje głównie od rodziny oraz członków organizacji „Ruch”. Tylko w trzech przypadkach udało mi się porozmawiać z podkomendnymi Gołębiewskiego z okresu okupacji. Pomocny okazał się także materiał fotograficzny. Na tej podstawie wiadomo chociażby, że w młodości był członkiem Ligi Obrony Powietrznej i Przeciwgazowej czy Legionu Młodych — Związku Pracy dla Państwa.

Duże znaczenie dla tej rozprawy miały źródła pamiętnikarskie, które konfrontowałam z materiałami archiwalnymi oraz opracowaniami dotyczącymi funkcjonowania ludzkiej pamięci. Wspomnę tu jedynie o obszernej relacji Gołębiewskiego z końca lat osiemdziesiątych, której przygotowanie do druku właściwie zainspirowało mnie do podjęcia tej tematyki.

Przyjęte w pracy ramy czasowe wyznaczają lata życia Mariana Gołębiewskiego — 19111996. Praca ma układ chronologiczny i chronologiczno-problemowy. Składa się ze wstępu, siedmiu rozdziałów, zakończenia, bibliografii oraz aneksu w postaci zdjęć. 
W pierwszym rozdziale opisałam środowisko rodzinne, aktywność zawodową do czasu wybuchu drugiej wojny światowej, wskazałam na elementy kształtujące charakter i światopogląd opisywanej przez mnie postaci, które miały wpływ na dokonywane w przyszłości wybory.

Drugi rozdział poświęciłam losom Gołębiewskiego po przekroczeniu przez niego we wrześniu 1939 r. granicy polsko-rumuńskiej, internowaniu w Rumuni, udziale w walkach 1 Dywizji Grenadierów we Francji i ucieczce z południowej Francji przez Hiszpanię, Portugalię oraz Gibraltar do Wielkiej Brytanii.

Trzeci rozdział przedstawia Gołębiewskiemu jako żołnierza Polskich Sił Zbrojnych w Wielkiej Brytanii i Armii Krajowej. Pokazałam, jak przebiegał proces rekrutacyjny cichociemnych i przeszkolenie prowadzone przez Oddział VI Sztabu Naczelnego Wodza i brytyjskie SOE. Kolejno omówiłam jego udział w tworzeniu Kedywu w Inspektoracie Zamość Armii Krajowej. Następnie, koncentrując się na sprawowanej przez niego od października 1943 r. funkcji komendanta Okręgu Hrubieszów AK, zwróciłam szczególną uwagę na takie wątki, jak: akcja scaleniowa, jego rola w przeforsowaniu ataku odwetowego na ukraińskie wioski z wiosny 1944 r., a także akcja „Burza”.

W czwartym rozdziale pracy zajęłam się analizą działalności Gołębiewskiego po wkroczeniu na Lubelszczyznę w lipcu 1944 r. Armii Czerwonej jako komendanta Obwodu Hrubieszów Armii Krajowej, a następnie inspektora Inspektoratu Zamość Delegatury Sił Zbrojnych, w końcu szefa sztabu i zastępcę komendanta Okręgu Lublin Zrzeszenia Wolność i Niezawisłość. W osobnym podrozdziale omówiłam okoliczności, w jakich w maju 1945 r. doszło do zawieszenia broni między podziemiem poakowskim a OUN-UPA, które objęło południową Lubelszczyznę, a następnie Podlasie. Gołębiewski usilnie zabiegał wówczas o zaakceptowanie tej umowy przez władze DSZ, a później KG WiN, nawet po zakazie współpracy podjętym na zebraniu 4 XI $1945 \mathrm{r}$.

W piątym, obszernym rozdziale zajmuję się więziennym okresem Gołębiewskiego. Pokazuję okoliczności jego aresztowania w styczniu 1946 r., podjętą grę z funkcjonariuszami UB, która zakończyła się niepowodzeniem i wbrew jego zamierzeniom przyczyniła się do kolejnych aresztowań w strukturach lubelskiego Zrzeszenia WiN. Ukazuję mechanizmy prowadzonego przez funkcjonariuszy MBP śledztwa i przygotowania do procesu. Właśnie fakt współpracy DSZ-WiN Okręgu Lublin z OUN-UPA przesądził o włączeniu Gołębiewskiego do pokazowego procesu przeciwko członkom I Zarządu Głównego Zrzeszenia Wolność i Niezawisłość, w którym jako jedyny został skazany na karę śmierci. W oddzielnym podrozdziale zajmuję się nieudaną ucieczką więźniów z Sieradza, którą zalicza się do największych tego typu nieudanych prób bez pomocy z zewnątrz w historii polskiego więziennictwa. Interesowały mnie szczególnie przyczyny, które sprawiły, że więźniowie w grudniu 1955 r. na czele z Marianem Gołębiewskim zdecydowali się na ten krok, w momencie gdy represyjność systemu znacznie już słabła.

Szósty rozdział dotyczy funkcjonowania Gołębiewskiego w PRL. Poruszam tu kilka zagadnień. Po pierwsze, opisuję jego niespełna roczną działalność w strukturach ZBoWiD na Lubelszczyźnie, w którą włączył się na fali przemian Października 1956 r. i w której dostrzegł przez moment możliwość stworzenia autentycznie akowskiej organizacji. Jednak już w grudniu 1957 r. został z niego usunięty, gdyż zarzucano mu, że zamierzał wykorzystać organizację do walki z komunizmem. Następnie omawiam podejmowane przez niego przez kilka lat próby wyjazdu za granicę. W dalszej części piszę, jak znajomość z rodziną profesora Ignacego Czumy przerodziła się w działalność niepodległościową w konspiracyjnej organizacji „Ruch”, w której pełnił rolę niekwestionowanego autorytetu i doradcy, za co ponownie trafił na cztery lata do więzienia. Rozdział kończy się ukazaniem jego aktywności w Ruchu Obrony Praw Człowieka i Obywatela do momentu wprowadzenia stanu wojennego. 
Ostatni rozdział zatytułowany Między emigracja a krajem odnosi się do działalności Gołębiewskiego w Stanach Zjednoczonych po wyjeździe tam w maju 1982 r., a także w Polsce po 1989 r. Wyjaśniam przyczyny, które złożyły się na decyzję o emigracji i pozostaniu na niej. Poruszam kontrowersyjną sprawę jego zaangażowania się po stronie samozwańczego „prezydenta” na uchodźstwie Juliusza Nowiny-Sokolnickiego i Konstantego Zygfryda Hanffa związanego z organizacją „Wolna Polska”, co niewątpliwie sprawiło, że przez część tamtejszej emigracji nie był traktowany jako partner do rozmowy. Piszę o jego zaangażowaniu na rzecz polsko-ukraińskiego porozumienia na emigracji, a następnie w kraju, w którym odegrał ważną rolę przez to, że jako świadek tamtych wydarzeń swoją publicystyką i spotkaniami przyczyniał się do upowszechniania wiedzy na ten temat. W końcu próbuję zrozumieć przyczyny, które sprawiły, że zajął postawę kwestionującą niepodległość Polski po 1989 r., w dość swoisty sposób ją rozumiejąc.

W wyniku podjętych badań powstała biografia opisująca życie Gołębiewskiego na trzech płaszczyznach: jako żołnierza, opozycjonisty oraz emigranta. Wykorzystany materiał źródłowy pozwolił na szerokie pokazanie jego losów i zweryfikowanie błędnych informacji funkcjonujących w literaturze przedmiotu. Biografia pokazuje obraz człowieka, który całe życie podporządkował służbie na rzecz niepodległej Polski, dla którego — jak zauważył jego syn — działalność polityczna była ważniejsza niż rodzina. Zasadniczy trzon jego osobowości ukształtował się w okresie II RP. Obecne w rodzinie tradycje pepeesowskiego POW, kult Józefa Piłsudskiego, środowisko seminarium nauczycielskiego, harcerstwo czy wreszcie zamiłowanie do sportu to istotne elementy kształtujące jego charakter. To głębokie poczucie obowiązku wobec ojczyzny wynikało zarówno z wymienionych czynników, jak i w okresie późniejszym z jego własnej interpretacji indywidualnego losu. 